\title{
Grass Seedling Recruitment in Cattle Dungpats
}

\author{
F. Gokbulak ${ }^{1}$ and C. A. Call ${ }^{2}$ \\ Authors are ${ }^{1}$ faculty member, Department of Watershed Management, Faculty of Forestry, University of Istanbul, \\ Istanbul, Turkey; and ${ }^{2}$ Associate Professor, Department of Forest, Range and Wildlife Sciences, Utah State University, \\ Logan, UT 84322. At the time of the research, Gokbulak was a research assistant in the Department of Forest, \\ Range and Wildlife Sciences, Utah State University, Logan, UT.
}

\begin{abstract}
Livestock seed dispersal (fecal seeding) is gaining recognition as a method to reintroduce desirable species to degraded rangelands. A field study was conducted to determine the influence of cattle dungpat thickness on the recruitment of Sandberg bluegrass (Poa secunda Presl.), bluebunch wheatgrass (Psuedoroegneria spicata [Pursh] A. Love), and 'Hycrest' crested wheatgrass (Agropyron desertorum [Fisch. ex Link] Schult. $\times$ A. cristatum [L.] Gaert.) in naturally and artificially deposited dungpats. Four Holstein heifers each were fed 60000 seeds of each species. Twenty-four hours after feeding seeds, dung was collected from 2 animals receiving each plant species and formed into uniform, artificial dungpats ( $2 \mathrm{~kg}$ in mass) with thicknesses of 1,2 , and $4 \mathrm{~cm}$, and respective diameters of 40,28 , and $20 \mathrm{~cm}$, and deposited on bare soil. The other 2 animals receiving each plant species were used to deposit natural dungpats, varying in mass, thickness, and diameter, on bare soil. Seedling recruitment in all dungpat types was greatest for crested wheatgrass, followed by Sandberg bluegrass and bluebunch wheatgrass. Recruitment for all species was generally greatest in 1-cm-thick artificial dungpats, followed in order by $2-\mathrm{cm}$-thick artificial dungpats, natural dungpats, and 4-cm-thick artificial dungpats. Most seedlings, regardless of species, emerged and survived in the interior region of 1-and 2-cmthick artificial dungpats and at the periphery of 4-cm-thick artificial dungpats. Most seedlings of crested wheatgrass and Sandberg bluegrass emerged and survived in cracks and depressions in the interior region of natural dungpats, whereas more bluebunch wheatgrass seedlings emerged and survived at the periphery of natural dungpats. Results indicate that the efficacy of cattle seed dispersal is influenced by the seedling vigor of species (seeds) consumed and the thickness of dungpats in which the ingested seeds are deposited. Grass species with weak seedling vigor (Sandberg bluegrass and bluebunch wheatgrass) have lower recruitment than species with strong seedling vigor (crested wheatgrass), particularly in dung $>2 \mathrm{~cm}$ thick.
\end{abstract}

\section{Resumen}

La dispersion de semillas por parte del ganado (sembrado por medio de las heces) esta ganando reconocimiento como metodo para reintroducir especies deseables en pasturas naturales deradadas. Se llevo a cabo un estudio a campo para determinar la influencia del espesor de las heces de ganado vacuno en el establecimiento de Sandberg bluegrass (Poa secunda Presl.), bluebunch wheatgrass (Psuedoroegneria spicata [Pursh] A. Love), y 'Hycrest' crested wheatgrass (Agropyron desertorum [Fisch. ex Link] Schult. $\times$ A. cristatum [L.] Gaert.) en heces depositadas natural y artificialmente. Cuatro vacas Holstein consumieron 60000 semillas de cada especie. Veinticuatro horas luego de consumir las semillas, se recolectaron las heces de dos animales que recbieron cada especie, formandose muestras uniformes ( $2 \mathrm{~kg}$ en masa) con espesores de 1,2 y $4 \mathrm{~cm}$, y diametros respectivos de 40,28, y $20 \mathrm{~cm}$, depositandose las muestras en suelo descubierto. Los otros do animales que recibieron las especies vegetales se utilizaron para el deposito de heces en forma natural, variando en masa, espesor y deametro en suelo descubierto. El reclutamiento de plantulas en todos los tipos de excremento fue mayor para crested wheatgrass, seguido por Sandberg bluegrass y bluebunch wheatgrass. El reclutamiento para todas las especies fue generalmente mayor para excrementos artificiales de $1 \mathrm{~cm}$ espesor, seguido en orden por excrementos artificiales de $2 \mathrm{~cm}$ de espesor, excrementos naturales, y excrementos artificiales de $4 \mathrm{~cm}$ de espesor. Muchas de las plantulas, independientemente de las especies consideradas, emergieron y sobrevivieron en la region interior de excrementos artificiales de 1 y $2 \mathrm{~cm}$ de espesor y en la periferia de excrementos artificiales de $4 \mathrm{~cm}$ de espesor. Muchas sobrevivieron en fracturas y depresiones en la region interior de los excrementos naturales, mientras que mas plantulas de bluebunch wheatgrass emergieron y sobrevivieron en la periferia de los excrementos naturales. Los resultados indican que la eficacia de la dispersion de semillas por medio de ganado vacuno esta influenciada por el vigor de las plantulas de las especies (semillas) consumidas y por el espesor de las heces en donde las semillas ingeridas son depositadas. Las especies de gramineas con un vigor de plantula debil (Sandberg bluegrass y bluebunch wheatgrass) tienen menor establecimiento que las especies con un vigor de plantula superior (crested wheatgrass), particularmente en heces de $2 \mathrm{~cm}$ de espesor.

Key Words: fecal seeding, revegetation, seed dispersal, seedling emergence, seedling establishment

This research was supported by the Utah Agricultural Experiment Station, Utah State University. Approved as Utah Agricultural Experiment Station Journal Paper 7413.

Correspondence: Dr Christopher Call, Dept of Forest, Range, and Wildlife Sciences, UMC5230, Utah State University, Logan, UT 84322. Email: cacall@cc.usu.edu

Manuscript received 2 October 2001; manuscript accepted 31 May 2004.

\section{Introduction}

Cattle and other livestock can be fed seeds of desirable plant species and then be released to disperse ingested seeds on rangelands. Depending on the rate of seed passage and on patterns of animal movement, seeds could be distributed in dung over a large area for several days after ingestion (Archer and Pyke 1991). Cattle dungpats can create favorable microsites for the germination of passed seeds and for subsequent plant establishment (Ocumpaugh et al 1996). 
Plant recruitment from passed seeds in cattle dungpats has been monitored for grass, forb, and woody species in arid, semiarid, and mesic rangeland environments (Welch 1985; Brown and Archer 1987; Barrow and Havstad 1992; Gardner et al 1993; Akbar 1994; Ocumpaugh et al 1996; Auman et al 1998). Artificially deposited dungpats were used in place of naturally deposited dungpats in several of these studies (Barrow and Havstad 1992; Gardner et al 1993; Akbar 1994; Ocumpaugh et al 1996; Auman et al 1998) because 1) dung can be mixed prior to deposition to ensure a more even distribution of passed seeds in dungpats; 2) uniformity in size and shape reduces the variability in dungpat features (diameter, thickness, cracks, depressions) that influence germination and seedling development; and 3) dungpats can be easily placed on different substrates in a variety of locations. However, there is little information available concerning the effects of dungpat thickness on seedling recruitment, or comparing seedling recruitment in uniform, artificially deposited dungpats to that in more variable, naturally deposited dungpats. Also, seedling vigor ratings (ie, weak, fair, strong) were not mentioned for the species in any of these studies. Grass seedlings with weak or fair seedling vigor have higher emergence when seeds are located in the upper $2 \mathrm{~cm}$ of most soil seedbeds (McKell 1972; Wasser 1982), indicating that seedling recruitment might be higher in dungpats $<2 \mathrm{~cm}$ thick. Cattle dungpats ranging in thickness from 3-10 cm have been used in other experiments (Barrow and Havstad 1992; Gardner et al 1993; Akbar 1994; Malo and Suarez 1995; Auman et al 1998).

The objectives of this study were to 1) determine the influence of cattle dungpat thickness on the recruitment of perennial grass species with different seedling vigor ratings; and 2) compare seedling recruitment in uniform, artificially deposited dungpats to recruitment in more variable, naturally deposited dungpats.

\section{Materials and Methods}

Bluebunch wheatgrass (Psuedoroegneria spicata [Pursh] A. Love), Sandberg bluegrass (Poa secunda L.), and Hycrest crested wheatgrass (Agropyron desertorum [Fisch. ex Link] Schult. $\times A$. cristatum [L.] Gaert.) were selected for this experiment on the basis of their desirability as revegetation species, differences in niches they occupy in upland range communities in the Intermountain West, and differences in their seed size and seedling vigor. The 3 species are adapted to low rainfall and most soil textures, and provide excellent spring forage for livestock and a variety of wildlife species (Wasser 1982; Asay et al 1991). Bluebunch wheatgrass and crested wheatgrass have a taller bunchgrass growth habit and a deeper root system than Sandberg bluegrass (Wasser 1982). Seeds (florets) of the 3 species are approximately the same diameter (1-2 $\mathrm{mm})$; however, the length of bluebunch wheatgrass seeds $(8-9 \mathrm{~mm})$ and Hycrest crested wheatgrass seeds $(7-8 \mathrm{~mm})$ is twice that of Sandberg bluegrass seeds $(3-4 \mathrm{~mm})$. Bluebunch wheatgrass seeds $\left(2.3 \mathrm{mg} \mathrm{seed}^{-1}\right)$ and Hycrest crested wheatgrass seeds $\left(2.1 \mathrm{mg} \mathrm{seed}^{-1}\right)$ have about four times the mass of Sandberg bluegrass seeds $\left(0.5 \mathrm{mg} \mathrm{seed}^{-1}\right)$. Seedling vigor and stand establishment for the 3 species are rated as: Hycrest crested wheatgrass $>$ bluebunch wheatgrass $>$ Sandberg blue- grass (Wasser 1982; Asay et al 1991). None of the 3 species require pretreatment for germination of seeds (Evans et al 1977; Young et al 1981; Asay et al 1991). Seeds of all 3 species can survive passage through the cattle digestive tract (Gokbulak 1998).

The experiment was conducted at the Utah State University (USU) Green Canyon Research Area located $4 \mathrm{~km}$ north of the USU campus (lat $41^{\circ} 46^{\prime} \mathrm{N}$, long $111^{\circ} 48^{\prime} \mathrm{W}$ ), at an elevation of $1460 \mathrm{~m}$. The gravelly loam soil (loamy-skeletal, carbonic, mesic, Typic Haploxeroll) is well drained and has a $\mathrm{pH}$ of 7.9. Dominant vegetation consists of big sagebrush (Artemisia tridentata ssp. tridentata Nutt.), bluebunch wheatgrass, and arrowleaf balsamroot (Balsamorhiza sagittata [Pursh] Nutt.) (USDA 1974). Average annual precipitation is about $420 \mathrm{~mm}$ and most of it falls as snow from November through March. Summers are generally dry. The average yearly maximum and minimum temperatures are $14.8^{\circ} \mathrm{C}$ and $2.8^{\circ} \mathrm{C}$, respectively. The highest daily temperature in summer can reach $37.8^{\circ} \mathrm{C}$, and the lowest daily temperature in winter can reach $-29.4^{\circ} \mathrm{C}$. The frost-free season is about 130 days (Ashcroft et al 1992).

Twelve Holstein heifers (age $10 \pm 0.3$ months, weight $250 \pm 12 \mathrm{~kg}$; mean $\pm \mathrm{SE}$ ) at the USU Caine Dairy Farm (located $15 \mathrm{~km}$ south of the USU campus) were used to generate dung containing passed seeds of the selected grass species. All animals were fed a grass hay diet (Bromus inermis Leysser, Dactylis glomerata L., Festuca arundinacea Schreb., Phleum pratense L., Juncus spp.; $69 \%$ in vivo dry matter digestibility, $7.8 \%$ crude protein, $63.6 \%$ neutral detergent fiber, and $32.9 \%$ acid detergent fiber), and had continuous access to water. Daily feed was offered at $3 \%$ of live body weight to each animal, and feed was equally divided between feeding times at 0800 hours and 1800 hours. There was a 5-day adjustment period to allow the heifers to accustom themselves to the diet and their surroundings prior to feeding them seeds. Four animals each were fed 60000 seeds of bluebunch wheatgrass, Sandberg bluegrass, or Hycrest crested wheatgrass. Of the 4 animals, 2 provided dung for artificial dungpat treatments and 2 were used to deposit dung for the natural dungpat treatment.

Dung for the artificial dungpat treatments was collected at the time of maximum seed passage, 24-48 hours after seed ingestion (Gokbulak 1998; Al-Mashikhi 1993). The dung collected from each heifer (18-20 kg) was mixed (by hand) to more uniformly distribute passed seeds, and stored in covered plastic containers to minimize water loss. At the field site, dung was divided into $2-\mathrm{kg}$ portions and poured into aluminum circular molds to form dungpats with different diameters and thicknesses. The 3 artificial dungpat treatments had diameters of 20,28 , and $40 \mathrm{~cm}$, with respective thicknesses of 4,2 , and 1 $\mathrm{cm}$. Each heifer provided enough dung to make 3 dungpats for each artificial dungpat treatment. For the natural dungpat treatment, heifers were transported to the field site at the time of maximum seed passage and confined to small pens $(4 \mathrm{~m} \times 4$ m) until they each deposited 3 dungpats.

Artificial and natural dungpats were deposited on bare soil at a minimum of $0.5 \mathrm{~m}$ apart from each other. Naturally deposited dungpats varied in mass $(0.8-2.5 \mathrm{~kg})$, diameter (20$40 \mathrm{~cm})$, and thickness $(1-5 \mathrm{~cm})$. Since the mass of most natural dungpats was $<2 \mathrm{~kg}$, the number of seedlings emerged was adjusted to those for artificial dungpats on a dungpat volume basis (straight proportion). The experiment was arranged in 
a completely randomized design with 6 samples (dungpats) for each plant species/dungpat type treatment combination.

Dungpats were monitored for seedling recruitment (live seedlings minus dead seedlings) on a weekly basis from April 13 to August 3 during the 1998 growing season. Emerged seedlings were grouped into weekly cohorts and marked with colored wire rings to note their time and location of emergence, and survival on dungpats. Seedling locations on dungpats were designated as peripheral (outer edge of dungpat) and interior (just inside outer edge to center of dungpat) regions.

Because of inherent differences in numbers of passed, germinable seed and in seedling vigor among the 3 grass species, statistical comparisons of seedling recruitment data were made among dungpat types within each species. The effects of dungpat type and dungpat region on seedling numbers for each species at the time of maximum recruitment and end of season recruitment were analyzed with a generalized linear mixed model using SAS macro GLIMMIX (SAS 2001). The statistical model is a 2-way factorial in a split-plot design, in which the whole plot unit is a sample (dungpat), the whole plot factor is dungpat type (with 4 levels), the subplot unit is a portion of the sample, and the subplot factor is dungpat region ( 2 levels). A Poisson distribution was specified for the error structure, with a (natural) log link. To deal with treatment combinations in which the number of seedlings was 0 (thus giving a mean of 0 and a variance of 0 ), a constant $(0.5)$ was added to all data values before analysis. Pairwise comparisons for dungpat type means were made with the Tukey-Kramer test $(P<0.05)$, and pairwise comparisons for dungpat type $\times$ dungpat region interaction means were made with an unconstrained step-down test $(P<0.05)$ (Westfall et al 1999).

Seedling survival over the course of the growing season (proportional survival) was analyzed using the survival package in the NCSS 2000 Statistical System (Hintz 1999). Survival plots were analyzed for best fit by examining the log-likelihoods for each distribution. A log-rank test (Lee 1992) was used to determine differences $(P<0.05)$ between the survival curves of the different dungpat types for each species.

\section{Results}

Seedlings of Sandberg bluegrass (Fig. 1a), bluebunch wheatgrass (Fig. 1b), and crested wheatgrass (Fig. 1c) began emerging from the different dungpat types 2-3 weeks after dung deposition, and continued emerging until week 8 . Recruitment remained low for Sandberg bluegrass on all dungpat types except $1-\mathrm{cm}$ thick artificial dungpats until week 5 . Recruitment was also low for bluebunch wheatgrass and crested wheatgrass on 4-cm-thick artificial dungpats and natural dungpats until week 5. Frequent, above-normal precipitation events, particularly those 5-7 weeks after dung deposition (Fig. 2), promoted seedling recruitment in all dungpat types. Maximum recruitment in most dungpat types occurred at week 8 for Sandberg bluegrass, and week 7 for bluebunch wheatgrass and crested wheatgrass. Seedling numbers declined for the 3 species in all dungpat types during the remainder of the study.

\section{Maximum Recruitment}

The number of seedlings per dungpat differed among dungpat types $(P<0.01)$ for the 3 species at the time of maximum (a)

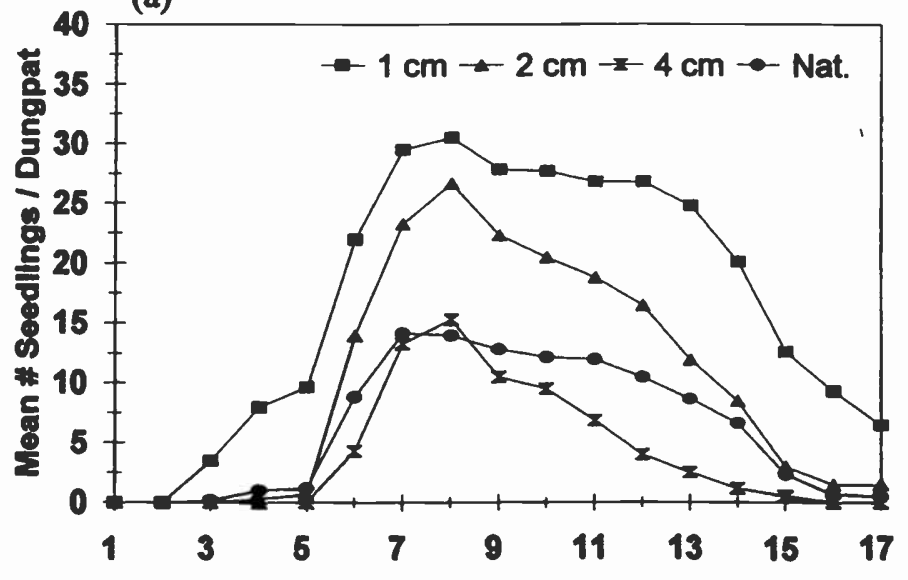

(b)

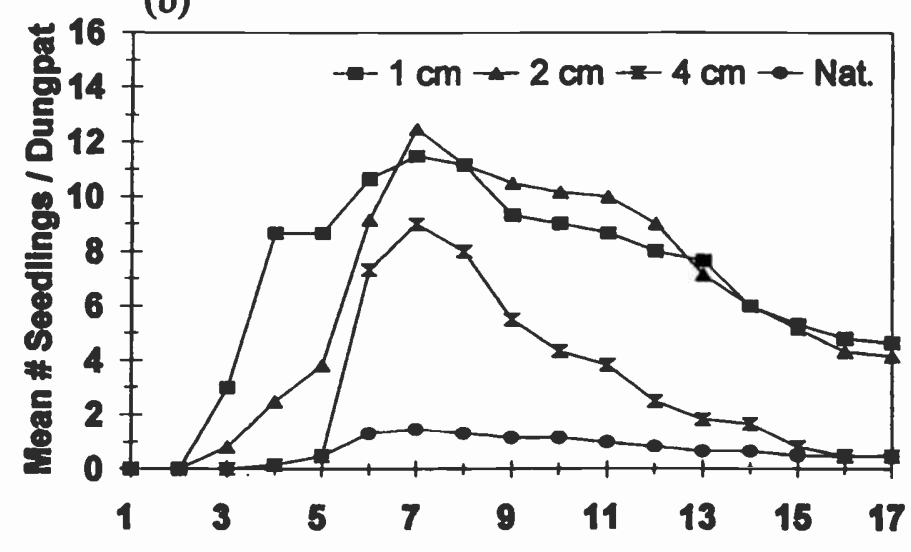

(c)

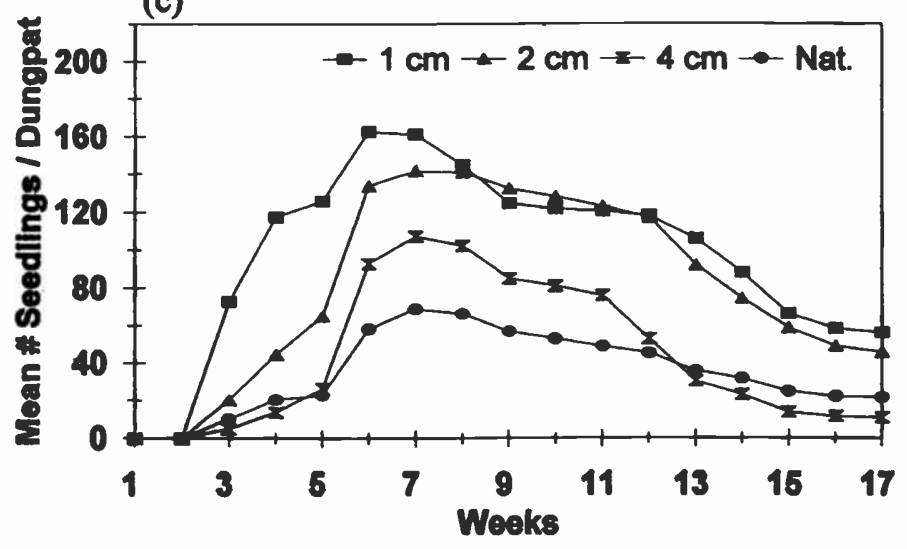

Figure 1. Mean number of (a) Sandberg bluegrass, (b) bluebunch wheatgrass, and (c) crested wheatgrass seedlings per dungpat in 1-, 2-, and 4-cm-thick artificial dungpats and natural dungpats from April 13 (Week 1) to August 3 (Week 17) during the 1998 growing season.

recruitment (see Entire dungpat data, Table 1). Recruitment was generally greatest in 1-cm-thick artificial dungpats, followed in order by 2 -cm-thick artificial dungpats, 4 -cm-thick artificial dungpats, and natural dungpats. Seedling numbers were significantly lower $(P<0.05)$ when dungpat thickness was $>2 \mathrm{~cm}$, ie, 4-cm-thick artificial dungpats for Sandberg bluegrass and crested wheatgrass, and natural dungpats (variable thickness, 1$5 \mathrm{~cm}$ ) for all 3 species. 


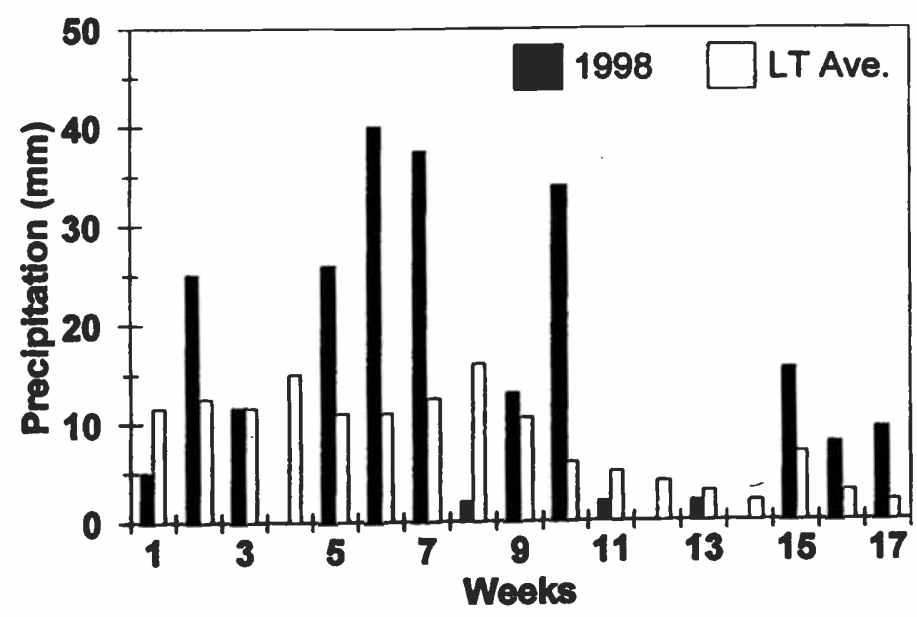

Figure 2. Weekly precipitation from April 13 (Week 1) to August 3 (Week 17) for the 1998 growing season and the long-term average (LT Ave.) at the study site.

Seedling numbers at peripheral and interior regions of dungpats differed among dungpat types (dungpat type by dungpat region interaction, $P<0.02$ ) for the 3 species (see Interior and Periphery data, Table 1). Sandberg bluegrass and bluebunch wheatgrass seedling numbers were higher $(P<0.05)$ in the interior than at the periphery of $1-$ and 2$\mathrm{cm}$-thick artificial dungpats (and natural dungpats for Sandberg bluegrass), and higher $(P<0.05)$ at the periphery than in the interior of 4-cm-thick artificial dungpats. Crested wheatgrass had more $(P<0.05)$ seedlings in the interior than at the periphery for all dungpat types.

Table 1. Mean ( \pm SE) number of Sandberg bluegrass, bluebunch wheatgrass, and crested wheatgrass seedlings (per dungpat) emerging at interior and peripheral regions in 1-, 2-, and 4-cm-thick artificial dungpats and natural dungpats at the time of maximum seedling recruitment. Data for interior and peripheral regions have also been combined to provide total seedling emergence (across the entire dungpat) for each dungpat type.

\begin{tabular}{lrcrr}
\hline & \multicolumn{5}{c}{ Dungpat type } \\
\cline { 2 - 5 } Dungpat region & $1 \mathrm{~cm}$ & $2 \mathrm{~cm}$ & $3 \mathrm{~cm}$ & Natural \\
\hline \multicolumn{5}{c}{ Sandberg bluegrass } \\
Interior & $28.0 \pm 4.1$ & $22.8 \pm 4.0$ & $2.8 \pm 0.8$ & $10.0 \pm 2.5$ \\
Periphery & $2.5 \pm 0.8$ & $3.8 \pm 1.1$ & $12.5 \pm 2.5$ & $4.1 \pm 1.3$ \\
Entire dungpat & $30.5 \pm 4.0$ & $26.6 \pm 4.8$ & $15.3 \pm 2.6$ & $14.1 \pm 2.5$ \\
& \multicolumn{5}{c}{ Bluebunch wheatgrass } \\
Interior & $9.8 \pm 2.0$ & $9.6 \pm 1.8$ & 0.0 & $0.8 \pm 0.4$ \\
Periphery & $1.7 \pm 0.6$ & $2.9 \pm 1.1$ & $9.0 \pm 1.4$ & $0.7 \pm 0.4$ \\
Entire dungpat & $11.5 \pm 1.8$ & $12.5 \pm 2.6$ & $9.0 \pm 1.4$ & $1.5 \pm 0.5$ \\
& \multicolumn{5}{c}{ Crested wheatgrass } \\
Interior & $133.3 \pm 12.6$ & $113.4 \pm 13.6$ & $79.8 \pm 8.0$ & $52.2 \pm 8.2$ \\
Periphery & $29.3 \pm 4.6$ & $28.4 \pm 4.8$ & $27.5 \pm 6.2$ & $16.6 \pm 4.1$ \\
Entire dungpat & $162.6 \pm 13.2$ & $141.8 \pm 11.8$ & $107.3 \pm 10.2$ & $68.8 \pm 9.1$ \\
\hline
\end{tabular}

Table 2. Mean ( \pm SE) number of Sandberg bluegrass, bluebunch wheatgrass, and Hycrest crested wheatgrass seedlings (per dungpat) surviving at interior and peripheral regions in 1-, 2-, and 4-cm-thick artificial dungpats and natural dungpats at the end of the study period. Data for interior and peripheral regions have also been combined to provide total seedling emergence (across the entire dunpgat) for each dungpat type.

\begin{tabular}{lcccr}
\hline & \multicolumn{5}{c}{ Dungpat type } \\
\cline { 2 - 5 } Dungpat region & $1 \mathrm{~cm}$ & $2 \mathrm{~cm}$ & $4 \mathrm{~cm}$ & Natural \\
\hline \multicolumn{5}{c}{ Sandberg bluegrass } \\
Interior & $5.8 \pm 1.9$ & $1.3 \pm 0.4$ & 0.0 & $0.3 \pm 0.2$ \\
Periphery & $0.7 \pm 0.3$ & $0.2 \pm 0.2$ & 0.0 & $0.2 \pm 0.2$ \\
Entire dungpat & $6.5 \pm 2.1$ & $1.5 \pm 0.7$ & 0.0 & $0.5 \pm 0.3$ \\
\multicolumn{5}{c}{ Bluebunch wheatgrass } \\
Interior & $3.6 \pm 1.3$ & $3.0 \pm 1.1$ & 0.0 & $0.2 \pm 0.2$ \\
Periphery & $1.0 \pm 0.4$ & $1.2 \pm 0.6$ & $0.5 \pm 0.3$ & $0.3 \pm 0.2$ \\
Entire dungpat & $4.6 \pm 1.5$ & $4.2 \pm 1.1$ & $0.5 \pm 0.3$ & $0.5 \pm 0.3$ \\
& \multicolumn{5}{c}{ Crested wheatgrass } \\
Interior & $48.1 \pm 8.2$ & $37.4 \pm 6.3$ & $5.2 \pm 1.6$ & $14.0 \pm 3.9$ \\
Periphery & $8.5 \pm 1.9$ & $8.8 \pm 2.4$ & $5.8 \pm 1.4$ & $8.0 \pm 2.5$ \\
Entire dungpat & $56.6 \pm 10.9$ & $46.2 \pm 7.3$ & $11.0 \pm 2.9$ & $22.0 \pm 3.7$ \\
\hline
\end{tabular}

\section{End of Season Recruitment}

The number of seedlings per dungpat also differed among dungpat types $(P<0.01)$ for the 3 grass species at the end of the study period (see Entire dungpat data, Table 2). Recruitment was generally greatest in 1-cm-thick artificial dungpats, followed in order by 2 -cm-thick artificial dungpats, natural dungpats, and 4-cm-thick dungpats. Lower $(P<0.05)$ seedling numbers remained in dungpats $>2 \mathrm{~cm}$ thick, ie, natural dungpats for bluebunch wheatgrass and crested wheatgrass, and 4-cm-thick artificial dungpats for all 3 species.

Seedling numbers at peripheral and interior regions of dungpats also varied among dungpat types (dungpat type by dungpat region interaction, $P<0.02$ ) for the 3 species (see Interior and Periphery data, Table 2). Recruitment remained higher $(P<0.05)$ in the interior than at the periphery of 1 - and 2 -cm-thick artificial dungpats for all 3 species (and natural dungpats for crested wheatgrass). Seedling numbers were similar $(P>0.05)$ in both regions of natural dungpats for Sandberg bluegrass and bluebunch wheatgrass, and both regions of 4-cm-thick artificial dungpats for crested wheatgrass. No Sandberg bluegrass seedlings remained in the interior or at the periphery of $4-\mathrm{cm}$-thick artificial dungpats.

\section{Survival}

The proportion of seedlings surviving to the start of each weekly interval in the different dungpat treatments for each species over the study period is shown in Figure 3. For Sandberg bluegrass (Fig. 3a), survival was higher $(P<0.05)$ in 1 -cm-thick artificial dungpats than in $2-\mathrm{cm}$-thick artificial dungpats and natural dungpats, and lowest $(P<0.05)$ in 4 -cm-thick artificial dungpats. There were no differences $(P>0.05)$ in survival in all dungpat types for bluebunch wheatgrass (Fig. 3b). For crested wheatgrass (Fig. 3c), survival in 4-cm-thick artificial dungpats was lower $(P<0.05)$ than in the other dungpat types. 
At the time of maximum seedling recruitment ( 6 weeks of life for Sandberg bluegrass and 5 weeks of life for bluebunch wheatgrass and crested wheatgrass), survival in all dungpat types was $\geq 80 \%$ for Sandberg bluegrass and bluebunch wheatgrass, and $\geq 90 \%$ for crested wheatgrass. By the end of the study period, the highest survival for the 3 species $(18 \%-$ $35 \%)$ was in $1-\mathrm{cm}$-thick artificial dungpats and the lowest $(0 \%-10 \%)$ was in $4-\mathrm{cm}$-thick artificial dungpats. Sandberg bluegrass had the lowest proportional survival among the 3 species for each dungpat type. Even though crested wheatgrass had higher numbers of surviving seedlings than bluebunch wheatgrass in all dungpat types (Fig. 1), proportional survival was similar for the 2 species (Fig. 3).

\section{Discussion}

Reductions in seedling numbers for crested wheatgrass, and particularly for Sandberg bluegrass and bluebunch wheatgrass, were more pronounced when dungpat thickness was $>2 \mathrm{~cm}$. This was evident in natural dungpats, where most seedlings of the 3 species emerged in cracks and depressions ( $<2 \mathrm{~cm}$ thick) compared to thicker regions $(4-5 \mathrm{~cm}$ thick). Since equivalentsized dung samples ( $2 \mathrm{~kg}$ ) were used for 1-, 2-, and 4-cm-thick artificial dungpats, lower recruitment in $4-\mathrm{cm}$-thick artificial dungpats was primarily due to the failure of seedlings to emerge from seeds at deeper depths $(>2 \mathrm{~cm})$. This seed depth/seedling emergence relation was documented in a companion greenhouse study (Gokbulak 1998) where pregerminated seeds of the 3 species were placed at depths of $0.5,2.0$, and $3.5 \mathrm{~cm}$ in $4-\mathrm{cm}-$ thick artificial dungpats, and dungpats were carefully broken apart after 60 days to recover emerged and nonemerged seedlings. Fewer emerged seedlings were recovered as planting depth changed from 0.5 to $3.5 \mathrm{~cm}$.

Grass seedling recruitment has been documented in other studies with artificially deposited cattle dungpats (Barrow and Havstad 1992; Gardener et al 1993; Akbar 1994; Ocumpaugh et al 1996; Auman et al 1998); however, only one dung thickness was used in each study, precluding any comparison of thickness on recruitment. Barrow and Havstad (1992) monitored the recruitment of alkali sacaton (Sporobolus airoides [Torr.] Torr.) and blue panicgrass (Panicum antidotale Retz.) in 5- to 10-cmthick (30-36 cm diameter) artificial dungpats in an arid grassland. Alkali sacaton and blue panicgrass averaged about 7 and 8 seedlings per dungpat, respectively, and both species flowered and set seed before the end of the growing season. Gardener et al (1993) followed the recruitment of 7 grass species in 3-cm-thick (30 cm diameter) artificial dungpats over a 28 week period (middle of dry season to middle of wet season) in a tropical grassland. Molasses grass (Melinis minutiflora Beauv.) was the only species to maintain relatively high seedling numbers (16 per dungpat), apparently because seed dormancy prevented seed losses in dung early in the study. Ocumpaugh et al (1996) reported that switchgrass (Panicum virgatum L.) recruitment and plant size were greater in fecal-seeded plots than in broadcast-seeded plots in a subtropical savanna pasture. They poured $600 \mathrm{~g}$ of cattle feces containing passed switchgrass seed on fecal-seeded plots, but did not indicate the thickness or diameter of the artificial dungpats. Akbar (1994) and Auman et al (1998) observed 4 to 8 crested wheatgrass seedlings per dungpat in 4-cm-thick ( $20 \mathrm{~cm}$ diameter) artificial dungpats at (a)

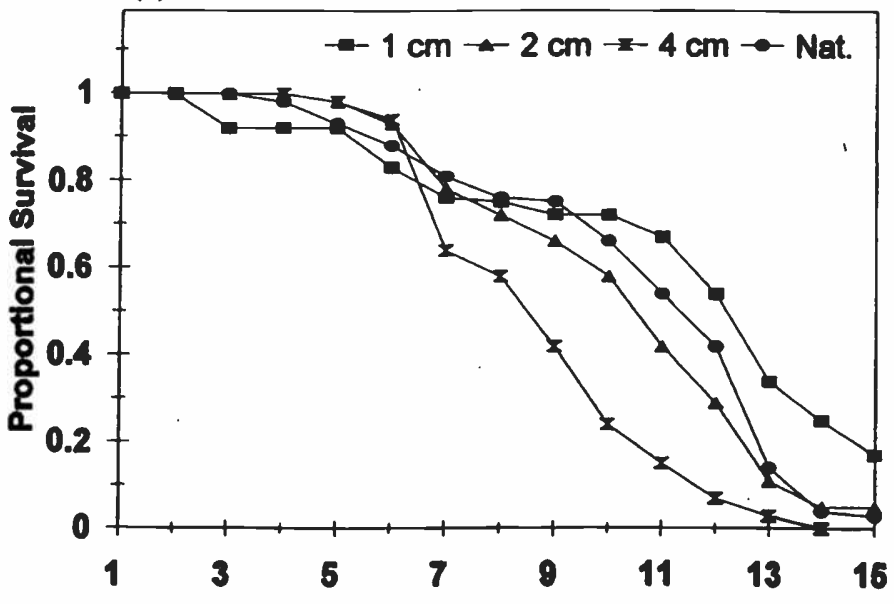

(b)

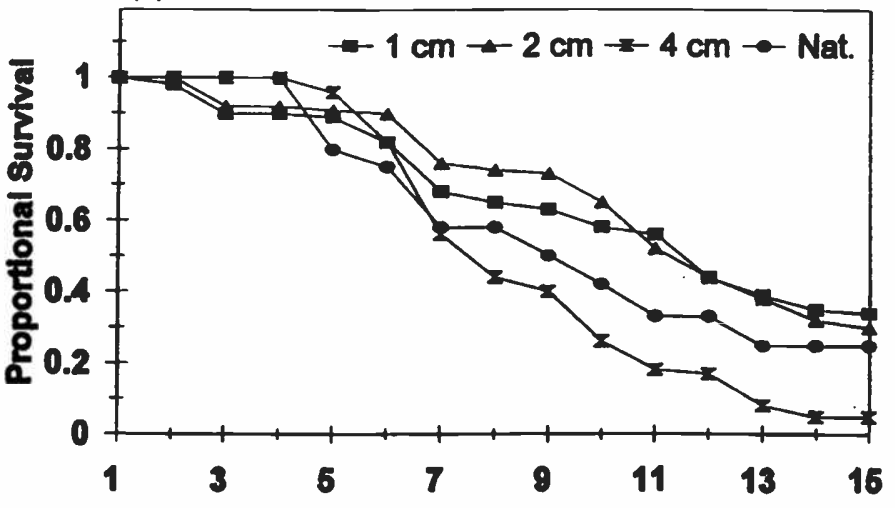

(c)

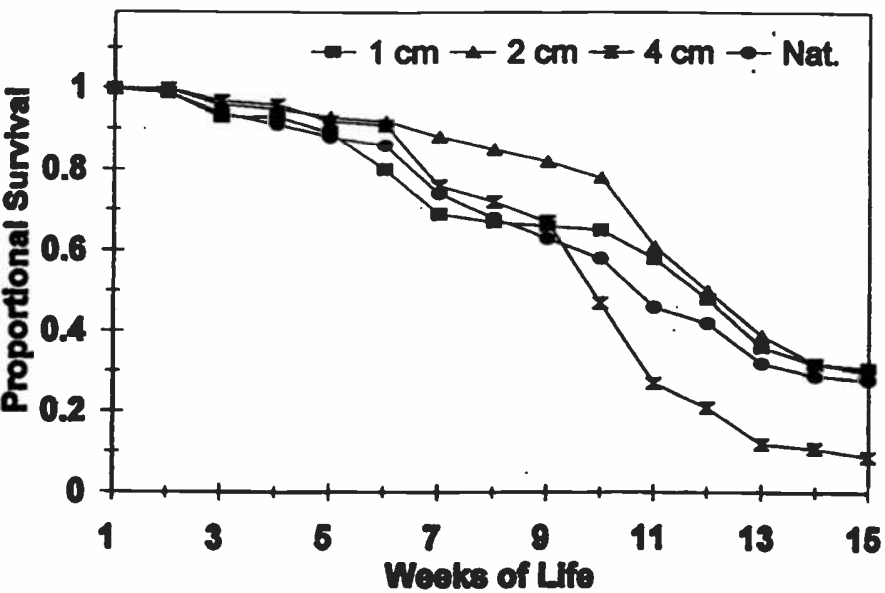

Figure 3. Proportional survival of (a) Sandberg bluegrass, (b) bluebunch wheatgrass, and (c) crested wheatgrass seedlings in 1-, 2-, and 4-cm-thick artificial dungpats and natural dungpats from April 27 (Week 1) to August 3 (Week 15) during the 1998 growing season. Seedlings emerged 2 to 3 weeks after the date of dung deposition (April 13).

the end of 43-week and 19-week study periods, respectively, in a sagebrush (A. tridentata Nutt.) steppe. In both studies, most of the crested wheatgrass seedlings emerged and established at the periphery of the dungpats. The few seedlings that did establish 
in the interior region of the dungpats were smaller and weaker than those at the periphery.

Dung thickness has had mixed effects on grass (and forb) recruitment in studies with naturally deposited cattle dungpats. After grazing cattle in a Mediterranean pasture when most grass and forb species had set seed, Malo and Suarez (1995) found fewer species on thick $(>3.5 \mathrm{~cm})$ than on thin $(<3.5$ $\mathrm{cm}$ ) dungpats, and more bare surface area on thick than on thin dungpats. In a similar study in a heather moorland, Welch (1985) found that the numbers of grass and forb species were greater on larger cattle dungpats but seemed unrelated to the depth of dung.

Surface crusts begin forming on cattle dungpats as soon as they are deposited in most environments, and the thickness of the crust typically increases with exposure time (Marsh and Campling 1970; Palmer and Bay 1982). In a previous experiment at our research site, Akbar (1994) observed that an 8-11 mm crust could develop on 4-cm-thick artificial dungpats within 4 weeks after dung deposition in the spring, and that it could inhibit crested wheatgrass seedling emergence unless it was softened by frequent precipitation events. In our study, above-normal precipitation 2, 5, 6, and 7 weeks after dung deposition softened the crust, allowing seedlings of Sandberg bluegrass, bluebunch wheatgrass, and crested wheatgrass to emerge in all dungpat treatments.

The ability of grass coleoptiles to elongate from different depths in dung (or soil) and penetrate through a surface crust is strongly related to seedling vigor (Booth and Haferkamp 1995). Seedling vigor ratings for the 3 species are based primarily on seed and seedling size, and the rate of seedling development (Wasser 1982; Asay et al 1991). Sandberg bluegrass (weak vigor) has small seed reserves and seedling size, and slow seedling development; bluebunch wheatgrass (fair vigor) has larger seed reserves and seedling size, and moderate seedling development; and crested wheatgrass (strong vigor) has larger seed reserves and seedling size, and rapid seedling development. Seedlings of Sandberg bluegrass and bluebunch wheatgrass were able to penetrate through dung and surface crusts at all locations in 1- and 2-cm-thick artificial dungpats, and in natural dungpats where cracks and depressions reduced dung thickness to $<2 \mathrm{~cm}$. In 4-cm-thick artificial dungpats, bluebunch wheatgrass and Sandberg bluegrass seedlings emerged mostly or entirely at the periphery of dungpats near the soil surface where coleoptile elongation was not impeded by dung. Seedlings of crested wheatgrass were able to penetrate through dung and surface crusts at all locations in all dungpat types. In contrast to other species, the more vigorous crested wheatgrass seedlings had higher emergence in the interior region than at the periphery of 4-cm-thick artificial dungpats.

Differences in seedling numbers per dungpat among the 3 species in the dungpat types are not only due to differences in seedling vigor, but also differences in the amount of passed, germinable seeds in dungpats. Results from a preliminary seedfeeding trial associated with this study (Gokbulak 1998) and from a related study (Al-Mashikhi 1993) showed that when 60000 seeds of each species were fed to Holstein heifers (as in our study), the number of passed seeds in dung 24 hours after ingestion was greater for crested wheatgrass $\left(\sim 345\right.$ seeds $\mathrm{kg}^{-1}$ ) than for Sandberg bluegrass $\left(\sim 135\right.$ seeds $\left.\mathrm{kg}^{-1}\right)$ and bluebunch wheatgrass $\left(\sim 175\right.$ seeds $\left.\mathrm{kg}^{-1}\right)$, and the percent germinability of passed seeds was also greater for crested wheatgrass (52\%) than for Sandberg bluegrass $(21 \%)$ and bluebunch wheatgrass $(14 \%)$. On the basis of these data, there may have been about 360,60 , and 50 germinable seeds, respectively, of crested wheatgrass, Sandberg bluegrass, and bluebunch wheatgrass in the 2-kg dung samples used to prepare 1-, 2-, and 4-cm-thick artificial dungpats. The presence of about 360 germinable seeds in each dungpat accounts, in part, for the high numbers of crested wheatgrass seedlings in artificial (and natural) dungpats at the time of maximum recruitment.

Seedling density, resource availability, and seedling vigor can strongly influence seedling survivorship (Begon et al 1990; Booth and Haferkamp 1995). There are limited resources (water and nutrients) available for plant growth in dungpats and the underlying soil, and at high seedling densities, intraspecific competition leads to decreased rates of resource uptake per individual and possibly decreased rates of individual growth or development (Begon et al 1990). Although seedling numbers in artificial dungpats at the time of maximum recruitment were generally highest for all 3 species in 1-cm-thick dungpats, followed in order by 2 -cm-thick and 4-cm-thick dungpats, the trend for seedling densities (on the basis of dungpat area) was the reverse. The highest mortality for all 3 species occurred in 4$\mathrm{cm}$-thick artificial dungpats by the end of the study period. It is difficult to separate density-dependent mortality (intraspecific competition for resources) from substrate-induced mortality (thick dung slowing/impeding coleoptile and seminal root growth). It appears, however, that crested wheatgrass seedlings were affected more by density-dependent mortality because strong seedling vigor allowed high numbers of seedlings to readily emerge through dung $>2 \mathrm{~cm}$ thick. Bluebunch wheatgrass seedlings, and particularly Sandberg bluegrass seedlings, had much lower densities than crested wheatgrass seedlings in respective dungpat treatments and difficulty emerging through dung $>2 \mathrm{~cm}$ thick, so it appears that substrate-induced mortality played a greater role for these less vigorous species. Larger, early-developing seedlings generally outcompeted smaller, later-developing seedlings of the 3 species, regardless of dungpat type and seedling location in dungpats.

\section{Management Implications}

Although artificial dungpats and natural dungpats are presented as distinctly different treatments in this study, there may be more commonality among these dungpat types in certain field settings. The consistency of feces, and therefore the thickness of natural dungpats, is heavily influenced by the type of diet a ruminant animal consumes (Merchen 1988). A cow eating higher-quality spring forage or fresh hay with a high water content will expel looser feces that will form thin dungpats (1-2 $\mathrm{cm}$ thick). Cows on this diet could be fed seeds of species with lower seedling vigor ratings because seedlings would be able to penetrate through the thin dung layer and developing crust. A cow eating lower-quality fall forage with a lower moisture content will deposit more variable dungpats with much of the dungpat $>2 \mathrm{~cm}$ thick. Cows on this diet should be fed seeds of species with stronger vigor because seedlings would have to penetrate through thicker dung and a developing crust.

Managers must consider the ability of thin dungpats to suppress resident vegetation and allow desired seedlings to 
establish in the dungpats. Shoots of resident, perennial plants might have the reserves and the force to penetrate through 1 - to 2 - $\mathrm{cm}$-thick dung and continue growing, whereas resident annuals may not be able to penetrate through the dung. Auman et al (1998) observed that 4 -cm-thick (20-cm-diameter) cattle dungpats effectively suppressed annual (cheatgrass [Bromus tectorum L.]) and perennial (squirreltail [Elymus elymoides \{Raf.\} Sweezey]) vegetation. However, the crested wheatgrass seedlings that emerged primarily at the periphery of the dungpats were not able to compete with cheatgrass plants in their immediate vicinity. The crested wheatgrass seedlings might have survived if they had emerged and developed in the interior region of thinner, larger-diameter dungpats (assuming suppression of cheatgrass). Creating a large gap in resident vegetation with dungpats would be even more important for the establishment of species with weak seedling development characteristics, such as Sandberg bluegrass and bluebunch wheatgrass.

Another managerial consideration is the amount of seed to feed to get an adequate number of seedlings to emerge and establish in dungpats. In previous studies in the sagebrush steppe (Auman et al 1998; Akbar 1994), 4 to 8 mature plants established in 4-cm-thick dungpats prepared from dung where cows had been fed 60000 seeds. In our study, 60000 seeds of crested wheatgrass was too much seed for cows that would be depositing 1- to 2-cm-thick dungpats. The amount could possibly be reduced by half to prevent seed wastage and to reduce density-dependent mortality as seedlings compete for more limiting resources later in the growing season. Since crested wheatgrass seedling recruitment in natural dungpats was about twice that of 4-cm-thick artificial dungpats in our study, the seed feeding rate should probably be reduced, but not necessarily cut in half. The seed feeding rate for Sandberg bluegrass and bluebunch wheatgrass, and other species with low seedling vigor, should probably be increased if natural dungpats are going to be thick (up to $5 \mathrm{~cm}$ ) as in this study. The rate of 60000 seeds per animal appears to be reasonable for 1- and 2cm-thick dungpats.

\section{Acknowledgment}

We thank Susan Durham for statistical assistance.

\section{Literature Cited}

AKBAR, G. 1994. Dungpat microenvironmental effects on germination and establishment of crested wheatgrass [PhD dissertation]. Logan, UT: Utah State University. 138 p.

AL-MASHIKHI, M. S. 1993. Influence of the ruminant digestive process on the germination of range forage species [MS thesis]. Logan, UT: Utah State University. $26 \mathrm{p}$.

ArCheR, S., and D. A. PyKe. 1991. Plant-animal interactions affecting plant establishment and persistence on revegetated rangeland. Journal of Range Management 44:558-565.

Asay, K. H., M. D. Rumbaugh, and T. A. Jones. 1991. Improved grasses and forbs for Intermountain rangelands. In: L. F. James, J. O. Evans, M. H. Ralphs, and R. D. Childs [eds.]. Noxious range weeds., Boulder, CO: Westview Press. p 138-152.
Ashcroft, G. L., D. T. Jensen, And J. L. Brown. 1992. Utah climate. Utah Climate Center, Utah State University, Logan, UT.

Auman, B. S., C. A. Call, and R. D. Wiedmeier. 1998. Crested wheatgrass establishment in livestock dung deposited on degraded rangeland vegetation types in the Intermountain West, USA. Arid Soil Research and Rehabilitation 12:317-333.

BARROW, J. R., AND K. M. HavStAd. 1992. Recovery and germination of gelatinencapsulated seeds fed to cattle. Journal of Arid Environments 22:395-399.

Begon, M., J. L. Harper, and C. R. Townsend. 1990. Ecology: Individuals, populations, and communities. 2nd ed. Cambridge, MA: Blackwell Scientific Publications. $945 \mathrm{p}$.

Booth, D. T., AND M. R. Haferkamp. 1995. Morphology and seedling establishment. In: D. J. Bedunah and R. E. Sosebee [eds.]. Wildland plants: Physiological ecology and developmental morphology. Denver, CO: Society for Range Management. p 239-290.

Brown, J. R., AND S. ARCHER. 1987. Woody plant seed dispersal and gap formation in a North American subtropical savanna woodland: the role of domestic herbivores. Vegetatio 73:73-80.

Evans, R. A., J. A. Young, and B. A. Roundr. 1977. Seedbed requirement for germination of Sandberg bluegrass. Agronomy Journal 69:817-820.

Gardener, C. J., J. G. Mcivor, and A. Jansen. 1993. Passage of legume and grass seeds through the digestive tract of cattle and their survival in faeces. Journal of Applied Ecology 30:63-74.

GoKBULAK, F. 1998. Seed dispersal by livestock: A revegetation application for improving degraded rangelands [PhD dissertation]. Logan, UT: Utah State University. $116 \mathrm{p}$.

HINTZ, J. L. 1999. NCSS 2000-User's guide. Number Cruncher Statistical Systems; Kaysville, UT.

LeE, E. T. 1992. Statistical methods for survival data analysis. 2nd ed. New York, NY: John Wiley \& Sons. 557 p.

MALO, J. E., AND F. SUAREZ. 1995. Establishment of pasture species on cattle dung: the role of endozoochorus seeds. Journal of Vegetation Science 6:169-174.

MarSH, R., and R. C. Campling. 1970. Fouling of pastures by dung. Herbage Abstracts 40:123-130.

MCKELL, C. M. 1972. Seedling vigor and seedling establishment. In: V. B. Younger and C. M. Mckell [eds.]. The biology and utilization of grasses. New York, NY: Academic Press. p 74-89.

MerChen, N. R. 1988. Digestion, absorption and excretion in ruminants. In: D. C. Church [ed.]. The ruminant animal: Digestive physiology and nutrition. Englewood Cliffs, NJ: Prentice Hall. p 172-201.

OCumpaugh, W. R., S. ARCher, And J. W. Stuth. 1996. Switchgrass recruitment from broadcast seed vs. seed fed to cattle. Journal of Range Management 49: 368-371.

Palmer, W. A., and D. E. Bay. 1982. Moisture content of the dung pat as a factor in the survival of larval stages of the Horn fly, Haematobia irritans (L.). Protection Ecology 4:353-359.

SAS. 2001. The SAS system for windows. Release 8.02. Cary, NC: SAS Institute, Inc. USDA Soil Conservation Service, Forest Service, and Utah Agricultural Experiment Station. 1974. Soil survey of Cache Valley area, Utah (parts of Cache and Box Elder Counties). Washington, DC: U.S. Govt. Printing Office. 192 p.

WASSER, C. H. 1982. Ecology and culture of selected species in revegetating disturbed lands in the West. Washington, DC: U.S. Fish and Wildlife Service, U.S. Dept. of Interior. 347 p.

WELCH, D. 1985. Studies in the grazing of heather moorland in north-east Scotland. Journal of Applied Ecology 22:461-472.

Westfall, P. H., R. D. Tobias, D. Rom, R. D. Wolfinger, and Y. Hochberg. 1999. Multiple comparisons and multiple tests using the SAS system. Cary, NC: SAS Institute, Inc. 254 p.

Young, J. A., R. A. Evans, and R. E. Eckert. 1981. Temperature profiles for germination of bluebunch wheatgrass and beardless wheatgrass. Journal of Range Management 34:84-89. 